Терапевтична стоматологія

УДК 616.314.17-008.1:611.018.5:611.31:612.122

DOI 10.11603/2311-9624.2020.3.11569

(С. Є. Швець, М. О. Іськів

Львівський національний медичний університет імені Данила Галицького

e-mail: identist83@gmail.com

\title{
Ефективність застосування місцевої терапії на мікробіоценоз ротової порожнини у пацієнтів із генералізованим пародонтитом на тлі ураження шлунково-кишкового тракту
}

\section{ІНФОРМАЦІЯ}

Надійшла до редакціï/Received: 02.09.2020 p.

Ключові слова: генералізований пародонтит; мікробіоценоз; шлунково-кишковий тракт.

\section{АНОТАЦІЯ}

Резюме. Захворювання пародонта посідають друге місце за частотою і поширеністю після карієсу та залишаються актуальною проблемою у стоматології. Дана патологія виникає унаслідок дії цілого ряду факторів. Особливо часто патологічні процеси в пародонті зустрічаються у пацієнтів із загальносоматичними захворюваннями, зокрема в осіб із хворобами шлунково-кишкового тракту. Проведено порівняльне вивчення видового складу анаеробної мікрофлори пародонтальних кишень у пацієнтів із запально-деструктивними захворюваннями тканин пародонта на тлі Helicobacter pylori - acoційованої патології органів травлення після лікування, яке ми розробили.

Мета дослідження - з’ясувати клінічну ефективність місцевої терапії на мікробіоценоз ротової порожнини у пацієнтів із генералізованим пародонтитом на тлі ураження шлунково-кишкового тракту.

Матеріали і методи. Видовий склад анаеробних мікроорганізмів у пародонтальних кишенях вивчали у 52 пацієнтів (основна група) з генералізованим пародонтитом, у яких лікування захворювань пародонта проводилось із застосуванням запропонованої місцевої терапії, та 46 пацієнтів (порівняльна група) із ГП I-III ступенів тяжкості, у яких для лікування уражень тканин пародонта застосовувалась базисна місцева терапія. Детекцію патогенів у ротовій порожнині (вміст пародонтальних кишень) здійснювали методом мультипраймерної полімерно-ланцюгової реакції. Як засіб патогенетичної місцевої фармакотерапії, застосовували у вигляді аплікацій на ясна гель «Холісал». У якості місцевої фізіотерапії хворим на ГП I-III ступенів тяжкості основної групи проводили озонотерапію за допомогою озоногенератора «OzonyMed». Задля покращення і закріплення ефектів місцевої терапії застосовували полоскання, іригації, гідромасаж мінеральною водою «Моршинська», джерела № 1. Результати досліджень та їх обговорення. У віддалені терміни дослідження (12-18 місяців), незважаючи на незначне збільшення пацієнтів основної групи, у яких в пародонтальних кишенях були ідентифіковані анаеробні види мікроорганізмів, у 2,8 раза зменшилась кількість досліджуваних, у яких об’єктивізувались Helicobacter pylori та Treponema denticola; y 2,5 раза - з Fusobacterium nucleatum та Prevotella intermedia; в 1,7 раза - кількість носіїв Bacteroides forsythus, Porphyromonas gingivalis та Actinobacillus actinomycetemcomitans, (p<0,01). Кількість пацієнтів контрольної групи, де застосовувалась традиційна терапія при лікуванні ГП, у пародонтальних кишенях яких діагностувались анаеробні види мікроорганізмів, повернулась до референтних значень ( $>0,05)$.

Висновки. Зменшення кількості пацієнтів із ГП - носіїв анаеробних видів мікроорганізмів, засвідчує адекватність лікувально-профілактичного комплексу для лікування запальних захворювань тканин пародонта, який ми застосували. 
Вступ. Взаємозв'язок нижніх відділів шлунково-кишкового тракту і його початкового відділу - ротової порожнини - здійснюється за допомогою анатомічних, фізіологічних і гуморальних зв'язків [1]. У зв'язку з цим, в остані роки особливу увагу дослідників у стоматології та гастроентерології зосереджено на проблемі участі ротової порожнини у розвитку захворювань шлунково-кишкового тракту (ШКТ), тому що з одного боку, патологія травної системи, змінюючи параметри внутрішнього середовища організму, робить істотний вплив на стан ротової порожнини, з іншого боку, згідно з клінічними даними, патологічні процеси в ротовій порожнині стають вогнищами хронічної інфекції, i, порушуючи акт жування, призводить до порушення функції ШКТ і загострення його хронічних захворювань [2, 3].

Встановлено, що ротова порожнина є резервуаром Helicobacter pylori як одного з головних етіологічних факторів розвитку запальних захворювань ШКТ. Дослідження показали наявність Helicobacter pylori в самих різних локусах ротової порожнини: в слині, в ясенній рідині, на слизовій оболонці язика та щік, у пародонтальних кишенях [4]. Успішність застосування антигелікобактерної терапії у лікуванні гінгівіту та пародонтиту дозволило деяким авторам припустити можливу участь Helicobacter pylori у розвитку запалення тканин пародонта. Заселення ротової порожнини Helicobacter pylori стали враховувати як фактор, який впливає на розвиток і перебіг стоматологічних захворювань [5].

Ряд авторів розглядає ротову порожнину як своєрідну екологічну систему, в якій різні чинники - загальні та місцеві - спільно взаємодіючи, викликають різноманітні патологічні процеси [6]. Зміни в ротовій порожнині відображають закономірності патогенезу системної патології і зумовлені етіологічною, морфологічною та функціональною інтеграцією усіх систем організму [7]. 3 цієї причини проблема діагностики та лікування патології ротової порожнини виходить за межі стоматології, а знання особливостей проявів захворювань внутрішніх органів у ротовій порожнині важливо для лікаря-стоматолога в плані діагностики та з метою розробки комплексних підходів при лікуванні даної патології [8].

Матеріали і методи. Видовий склад анаеробних мікроорганізмів у пародонтальних кишенях у результаті застосування різних ме- дикаментозних засобів вивчали у 98 хворих після лікування та у віддалені терміни дослідження (12-18 місяців). Основну групу склали 52 пацієнти з генералізованим пародонтитом (ГП), у яких лікування захворювань пародонта проводилось із використанням запропонованої нами місцевої терапії. Групу порівняння склали 46 пацієнтів із ГП I-ІІІ ступенів тяжкості, у яких для лікування уражень тканин пародонта застосовували базисну місцеву терапію. Детекцію патогенів у ротовій порожнині (вміст пародонтальних кишень) здійснювали методом мультипраймерної полімерно-ланцюгової реакції [9]. Як засіб патогенетичної місцевої фармакотерапії застосовували у вигляді аплікацій на ясна гель «Холісал». У якості місцевої фізіотерапії хворим із ГП I-III ступенів тяжкості основної групи проводилась озонотерапія за допомогою озоногенератора «OzonyMed». Задля покращення і закріплення ефектів місцевої терапії застосовували полоскання, іригації, гідромасаж мінеральною водою «Моршинська», джерела № 1 [9, 10].

Результати досліджень та іх обговорення. У результаті проведених мікробіологічних досліджень (табл.) ми встановили, що після лікування у результаті застосування різних фармацевтичних препаратів вдалося значно нормалізувати мікробіологічний спектр пародонтальних кишень у пацієнтів обох груп дослідження. Однак у пацієнтів основної групи, у яких для лікування ГП різних ступенів тяжкості застосовували запропонований лікувально-профілактичний комплекс, зміни ідентифікації анаеробної мікрофлори у пародонтальних кишенях носили більш виражений позитивний характер. Так, у результаті застосування запропонованого нами лікувально-профілактичного комплексу, Helicobacter pylori діагностували у $(18,35 \pm 4,22) \%$ хворих проти $(69,50 \pm 4,21) \%$ до лікування $(\mathrm{p}<0,01)$. Bacteroides forsythus виявляли у $(15,37 \pm 4,27) \%$ обстежених проти $(42,12 \pm 4,23) \%$ до лікування, $(\mathrm{p}<0,01)$. Кількість хворих - носіїв Fusobacterium nucleatum після лікування зменшилась майже у 4,0 рази порівняно з референтними значеннями $((8,71 \pm 3,30) \%$ проти $(31,86 \pm 3,32) \%, \mathrm{p}<0,01)$.

Після лікування у $(17,82 \pm 4,20) \%$ пацієнтів основної групи виявляли Prevotella intermedia, що було у 2,8 раза менше стосовно даних до лікування $(50,58 \pm 4,21) \%, \mathrm{p}<0,01$. Porphyromonas gingivalis ідентифікували у $(27,13 \pm 4,19) \%$ хворих на ГП I-III ступенів тяжкості проти 
Таблищя. Видовий склад анаеробних мікроорганізмів у ясенних борознах та пародонтальних кишенях у хворих із на тлі уражень в різні лікувальні терміни (\%)

\begin{tabular}{|c|c|c|c|c|c|c|c|c|}
\hline $\begin{array}{l}\text { Термін } \\
\text { дослі- } \\
\text { джень }\end{array}$ & $\begin{array}{c}\text { Група } \\
\text { дослі- } \\
\text { джень }\end{array}$ & $\begin{array}{l}\text { Helico- } \\
\text { bacter } \\
\text { pylori }\end{array}$ & $\begin{array}{l}\text { Bacte- } \\
\text { roides } \\
\text { forsythus }\end{array}$ & $\begin{array}{c}\text { Fuso- } \\
\text { bacterium- } \\
\text { nucleatum }\end{array}$ & $\begin{array}{l}\text { Prevotella } \\
\text { intermedia }\end{array}$ & $\begin{array}{l}\text { Porphyro- } \\
\text { monas } \\
\text { gingivalis }\end{array}$ & $\begin{array}{l}\text { Actinoba- } \\
\text { cillus } \\
\text { actino- } \\
\text { myce- } \\
\text { temco- } \\
\text { mitans }\end{array}$ & $\begin{array}{l}\text { Trepo- } \\
\text { nemaden- } \\
\text { ticola }\end{array}$ \\
\hline \multirow[t]{2}{*}{$\begin{array}{l}\text { До ліку- } \\
\text { вання }\end{array}$} & $\begin{array}{c}\text { основна } \\
(n=52)\end{array}$ & $\begin{array}{c}69,50 \pm \\
4,21\end{array}$ & $\begin{array}{c}42,12 \pm \\
4,23\end{array}$ & $\begin{array}{c}31,86 \pm \\
3,32\end{array}$ & $\begin{array}{c}50,58 \pm \\
4,21\end{array}$ & $\begin{array}{c}51,00 \pm \\
4,22\end{array}$ & $\begin{array}{c}38,00 \pm \\
3,35\end{array}$ & $\begin{array}{c}52,25 \pm \\
4,49\end{array}$ \\
\hline & $\begin{array}{c}\text { контроль- } \\
\text { на } \\
(\mathrm{n}=46)\end{array}$ & $\begin{array}{c}69,25 \pm \\
4,20\end{array}$ & $\begin{array}{c}40,90 \pm \\
4,20\end{array}$ & $\begin{array}{c}30,80 \pm \\
3,32\end{array}$ & $\begin{array}{c}50,50 \pm \\
4,22\end{array}$ & $\begin{array}{c}51,25 \pm \\
4,20\end{array}$ & $\begin{array}{c}38,30 \pm \\
3,35\end{array}$ & $\begin{array}{c}50,90 \pm \\
4,48\end{array}$ \\
\hline \multirow[t]{2}{*}{$\begin{array}{l}\text { Після лі- } \\
\text { кування }\end{array}$} & $\begin{array}{c}\text { основна } \\
(\mathrm{n}=52)\end{array}$ & $\begin{array}{l}18,35 \pm \\
4,22^{* *}\end{array}$ & $\begin{array}{l}15,37 \pm \\
4,27^{* *}\end{array}$ & $\begin{array}{c}8,71 \pm \\
3,30^{* *}\end{array}$ & $\begin{array}{l}17,82 \pm \\
4,20^{* *}\end{array}$ & $\begin{array}{l}27,13 \pm \\
4,19 * *\end{array}$ & $\begin{array}{l}18,80 \pm \\
3,32^{* *}\end{array}$ & $\begin{array}{l}14,25 \pm \\
4,42^{* *}\end{array}$ \\
\hline & $\begin{array}{c}\text { контроль- } \\
\text { на } \\
(\mathrm{n}=46)\end{array}$ & $\begin{array}{l}30,48 \pm \\
4,21^{* *}\end{array}$ & $\begin{array}{c}29,50 \pm \\
4,22\end{array}$ & $\begin{array}{c}20,50 \pm \\
3,31^{*}\end{array}$ & $\begin{array}{l}32,15 \pm \\
4,15^{* *}\end{array}$ & $\begin{array}{l}38,0 \pm \\
4,16^{*}\end{array}$ & $\begin{array}{c}29,80 \pm \\
3,32\end{array}$ & $\begin{array}{c}36,48 \pm \\
4,42^{*}\end{array}$ \\
\hline \multirow{2}{*}{$\begin{array}{l}\text { Через 12- } \\
18 \text { місяців } \\
\text { після ліку- } \\
\text { вання }\end{array}$} & $\begin{array}{c}\text { основна } \\
(n=48)\end{array}$ & $\begin{array}{l}24,39 \pm \\
4,20^{* *}\end{array}$ & $\begin{array}{l}23,54 \pm \\
4,18^{* *}\end{array}$ & $\begin{array}{l}12,75 \pm \\
3,32^{* *}\end{array}$ & $\begin{array}{l}19,86 \pm \\
4,24^{* *}\end{array}$ & $\begin{array}{l}31,17 \pm \\
4,23^{* *}\end{array}$ & $\begin{array}{l}22,84 \pm \\
3,36^{* *}\end{array}$ & $\begin{array}{l}18,29 \pm \\
4,46^{* *}\end{array}$ \\
\hline & $\begin{array}{c}\text { контроль- } \\
\text { на } \\
(\mathrm{n}=43)\end{array}$ & $\begin{array}{c}69,22 \pm \\
4,21\end{array}$ & $\begin{array}{c}46,93 \pm \\
4,21\end{array}$ & $\begin{array}{c}35,12 \pm \\
3,35\end{array}$ & $\begin{array}{c}50,00 \pm \\
4,20\end{array}$ & $\begin{array}{c}51,90 \pm \\
4,21\end{array}$ & $\begin{array}{c}39,00 \pm \\
3,35\end{array}$ & $\begin{array}{c}58,40 \pm \\
4,42\end{array}$ \\
\hline
\end{tabular}

Примітки: 1) * - достовірність різниці значень стосовно даних контрольної групи, $\mathbf{p}<0,05$;

2) ** - достовірність різниці значень стосовно даних контрольної групи, $p<0,01$.

$(51,00 \pm 4,22) \%$ до лікування $(\mathrm{p}<0,01)$. Ми встановили, що після лікування у 2,0 рази зменшилась кількість хворих, носіїв Actinobacillus actinomycetemcomitans $(18,80 \pm 3,32) \%$ проти $(38,00 \pm 3,35) \%$ до лікування, $\mathrm{p}<0,01$. Treponema denticola об’єктивізувалсь у $(14,25 \pm 4,42) \%$ у пацієнтів після лікування проти $(52,25 \pm 4,49) \%$ до лікування $(\mathrm{p}<0,01)$.

Упацієнтів контрольноїгрупи після лікування найбільше знизилась кількість Helicobacter pylori - у 2,2 раза стосовно даних до лікування (p<0,01). Кількість пацієнтів контрольної групи, у яких ідентифікувались Fusobacterium nucleatum та Prevotella intermedia зменшилась у 1,5 раза стосовно вихідних значень ( $<<0,05$; $\mathrm{p}<0,01)$. Після лікування у хворих на ГП контрольної групи відзначали у 1,3 раза зменшення кількості пацієнтів, у яких в пародонтальних кишенях ідентифікувались Bacteroides forsythus $(p>0,05)$, Porphyromonas gingivalis $(p<0,05)$, Actinobacillus actinomycetemcomitans $(p>0,05)$ та Treponema denticola $(p<0,05)$. у віддалені терміни дослідження (12-18 місяців), незважаючи на незначне збільшення пацієнтів основної групи, в яких у пародонтальних кишенях були ідентифіковані анаеробні види мікроорганізмів, у 2,8 раза зменшилась кількість досліджуваних, в яких об'єктивізувались Helicobacter pylori та Treponema denticola; y 2,5 раза - 3 Fusobacterium nucleatum та Prevotella intermedia; у 1,7 paза - кількість носіїв Bacteroides forsythus, Porphyromonas gingivalis та Actinobacillus actinomycetemcomitans $(\mathrm{p}<0,01)$.

Кількість пацієнтів контрольної групи, де застосовувалась традиційна терапія при лікуванні ГП, у пародонтальних кишенях яких діагностувались анаеробні види мікроорганізмів, повернулась до референтних значень ( $>0,05)$.

Висновки. Зменшення кількості пацієнтів, хворих на ГП основної групи - носіїв анаеробних видів мікроорганізмів, засвідчує адекватність застосованого лікувально-профілактичного комплексу для лікування запальних захворювань тканин пародонта. 


\title{
Эффективность применения местной терапии на микробиоценоз полости рта у пациентов с генерализованным пародонтитом на фоне поражения желудочно-кишечного тракта
}

Резюме. Заболевания пародонта занимают второе место по частоте и распространенности после кариеса и остаются актуальной проблемой в стоматологии. Данная патология возникает вследствие действия целого ряда факторов. Особенно часто патологические процессы в пародонте встречаются у пациентов с общесоматическими заболеваниями, в частности у лиц с заболеваниями желудочнокишечного тракта. Проведено сравнительное изучение видового состава анаэробной микрофлоры пародонтальных карманов у пациентов с воспалительно-деструктивными заболеваниями тканей пародонта на фоне Helicobacter pylori - ассоциированной патологии органов пищеварения после разработанного нами лечения.

Цель исследования - выяснить клиническую эффективность местной терапии на микробиоценоз полости рта у пациентов с генерализованным пародонтитом на фоне поражения желудочно-кишечного тракта.

Материалы и методы. Видовой состав анаэробных микроорганизмов в пародонтальных карманах изучался в 52 пациентов (основная группа) с генерализованным пародонтитом, в которых лечение заболеваний пародонта проводилось с применением предложенной нами местной терапии, и 46 пациентов (сравнительная группа) с ГП I-III степеней тяжести, в которых для лечения поражений тканей пародонта применялась базовая местная терапия. Детекцию патогенов в полости рта (содержание пародонтальных карманов) осуществляли методом мультипраймерной полимерно-цепной реакции. Как средство патогенетической местной фармакотерапии применяли в виде аппликаций на десны гель «Холисал». В качестве местной физиотерапии больным ГП I-III степеней тяжести основной группы проводилась озонотерапия с помощью озоногенератора «OzonyMed». Для улучшения и закрепления эффектов местной терапии применяли полоскания, ирригации, гидромассаж минеральной водой «Моршинская», источники № 1.

Результаты исследований и их обсуждение. В отдаленные сроки исследования (12-18 месяцев), несмотря на незначительное увеличение пациентов основной группы, в которых в пародонтальных карманах были идентифицированы анаэробные виды микроорганизмов, в 2,8 раза уменьшилось количество исследуемых, у которых обьективизирувались Helicobacter pylori и Treponema denticola; в 2,5 раза - с Fusobacterium nucleatum и Prevotella intermedia; в 1,7 раза - количество носителей Bacteroides forsythus, Porphyromonas gingivalis и Actinobacillus actinomycetemcomitans $(p<0,01)$. Количество пациентов контрольной группы, где применялась традиционная терапия при лечении ГП, в пародонтальных карманах которых диагностировались анаэробные виды микроорганизмов, вернулось к референтным значениям ( $>0,05)$.

Выводы. Уменьшение количества пациентов с ГП - носителей анаэробных видов микроорганизмов, свидетельствует адекватность примененного нами лечебно-профилактического комплекса для лечения воспалительных заболеваний тканей пародонта.

ключевые слова: генерализованный пародонтит; микробиоценоз; желудочно-кишечный тракт.

\author{
CI. E. Shvets, M. O. Iskiv
}

Danylo Halytskyi Lviv National Medical University

\section{Effectiveness of application of local therapy on microbiocenosis of the oral cavity in patients with generalized periodontitis on the background of damage of the gastrointestinal tract}

Summary. Periodontal diseases are the second most common and prevalent after caries and remain an urgent problem in dentistry. This pathology occurs due to a number of factors. Pathological processes in the periodontium are especially common in patients with general somatic diseases, in particular in persons with diseases of the gastrointestinal tract. A comparative study of the species composition of the anaerobic microflora of periodontal pockets in patients with inflammatory-destructive diseases of periodontal tissues on the background of Helicobacter pylori - associated pathology of the digestive system after our treatment. 


\section{Терапевтична стоматологія}

The aim of the study - to determine the clinical efficacy of our developed local therapy for oral microbiocenosis in patients with generalized periodontitis on the background of gastrointestinal lesions.

Materials and Methods. The species composition of anaerobic microorganisms in periodontal pockets was studied in 52 patients (main group) with generalized periodontitis, in whom periodontal disease was treated using our proposed local therapy, and 46 patients (comparative group) with GP degree I-III of severity, in which basic local therapy was used to treat periodontal tissue lesions. Detection of pathogens in the oral cavity (contents of periodontal pockets) was carried out by the method of multi-polymer polymer-chain reaction. As a means of pathogenetic local pharmacotherapy was used in the form of applications on the clear gel "Holisal". As local physiotherapy, patients with GP degree I-III of severity of the main group underwent ozone therapy using an ozone generator "OzonyMed". In order to improve and consolidate the effects of local therapy, rinsing, irrigation, hydromassage with Morshynska mineral water, springs No. 1 were used.

Results and Discussion. In the long term (12-18 months), despite a slight increase in the main group of patients in whom anaerobic species of microorganisms were identified in periodontal pockets, the number of subjects in whom Helicobacter pylori and Treponema denticola were objectified decreased 2.8 times; 2.5 times - with Fusobacterium nucleatum and Prevotella intermedia; 1.7 times - the number of carriers of Bacteroides forsythus, Porphyromonas gingivalis and Actinobacillus actinomycetemcomitans $(\mathrm{p}<0.01)$. In patients of the control group, where traditional therapy was used in the treatment of GP, the number of patients in whose periodontal pockets were diagnosed with anaerobic species of microorganisms returned to the reference values $(\mathrm{p}>0.05)$.

Conclusions. Thus, the decrease in the number of patients with GP of the main group - carriers of anaerobic species of microorganisms, indicates the adequacy of our treatment and prevention complex for the treatment of inflammatory diseases of periodontal tissues.

Key words: generalized periodontitis; microbiocenosis; gastrointestinal tract.

\section{СПИСОК ЛІТЕРАТУРИ}

1. Prevalence of the generalized periodontitis in patients with different groups blood in depending on age and periodontal biotype/Yu. L. Bandrivsky, O. O. Bandrivska, R. Yu. Shkrebnyuk, V. T. Dyryk // Wiadomości Lekarskie. - 2020. - № 1 (73) - P. 119-122.

2. Зорина О. А. Микробиоценоз полости рта в норме и при воспалительных заболеваниях пародонта / О. А. Зорина, А. А. Кулаков, А. И. Грудянов // Стоматология. - 2011. - № 1. - С. 73-78.

3. Соотношение патогенных представителей микробиоценоза пародонтальных карманов при пародонтите разной степени тяжести / О. А. Зорина, А. А. Кулаков, О. А. Борискина, Д. В. Ребриков // Acta Naturae. - 2011. - T. 3, № 2 (9). - C. 101-104.

4. Гончарук Л. В. Взаимосвязь воспалительных заболеваний пародонта и соматической патологии / Л. В. Гончарук, К. Н. Косенко, С. Ф. Гончарук // Современная стоматология. - 2011. - № 1. - С. 37-40.

5. Горбачева Л. А. Общесоматические аспекты патогенеза и лечения генерализованного пародонтита / Л. А. Горбачева, А. И. Кирсанов, Л. Ю. Орехова // Сто- матология. - 2013. - Т. 80, № 1. - С. 26-34.

6. Данилевский Н. Ф. Заболевания пародонта / Н. Ф. Данилевский, А. В. Борисенко. - К. : Здоров’я, 2000. -466 c.

7. Генералізований пародонтит : монографія. Т. Д. Заболотний, В. Борисенко, В. Марков [та ін.]. Львів : ГалДент, 2011. - 239 с.

8. Заболотний Т. Д. Запальні захворювання пародонта / Т. Д. Заболотний, А. В. Борисенко, Т. І. Пупін. - Львів : ГалДент, 2013. - 206 с.

9. Бандрівський Ю. Л. Видовий склад анаеробної мікрофлори ясенних борозен та пародонтальних кишень у хворих з запально-деструктивними захворюваннями тканин пародонта на фоні патології органів шлунково-кишкового тракту / Ю. Л. Бандрівський, І. Є. Швець // Вісник проблем біології і медицини. - 2014. - № 4. - С. 309-312.

10. Petersen P. E. The global burden of oral diseases and risk to oral health / P. E. Petersen // Bull. World Health Organ. - 2015. - Vol. 83, No. 9. - P. 661-669.

\section{REFERENCES}

1. Bandrivsky, Y.L., Bandrivska, O.O., Shkrebnyuk, R.Y., \& Dyryk, V.T. (2020). Prevalence of the generalized periodontitis in patients with different groups blood in depending on age and periodontal biotype. Wiadomosci lekarskie, 73 (1), 119-122.

2. Zorina, O.A., Kulakov, A.A., \& Grudyanov, A.I. (2011). Mikrobiotsenoz polosti rta v norme i pri vospalitelnykh zabolevaniyakh parodonta [Microbiocenosis of the oral cavity in normal conditions and in inflammatory

periodontal diseases]. Stomatologiya - Dentistry, 1, 7378 [in Russian].

3. Zorina, O.A., Kulakov, A.A., Boriskina, O.A., \& Rebrikov, D.V. (2011). Sootnosheniye patogennykh predstaviteley mikrobiotsenoza parodontalnykh karmanov pri parodontite raznoy stepeni tyazhesti [The ratio of pathogenic representatives of microbiocenosis of periodontal pockets in periodontitis of varying severity]. Acta Naturae, 3, 2 (9), 101-104 [in Russian]. 
4. Honcharuk, L.V., Kosenko, K.N., \& Honcharuk, S.F. (2011). Vzaymosvyaz vospalytelnykh zabolevaniy parodonta i somaticheskoy patologii [Interrelation of inflammatory periodontal diseases and somatic pathology]. Sovremennaya stomatologiya - Modern Dentistry, 1, 37-40 [in Russian].

5. Horbacheva, L.A., Kyrsanov, A.Y., \& Orekhova, L.Yu. (2013). Obshchesomatycheskye aspekty patogeneza i lecheniya generalizovannogo parodontita [Somatic aspects of the pathogenesis and treatment of generalized periodontitis]. Stomatologiya - Dentistry, 80, 1, 26-34 [in Russian].

6. Danylevskyy, N.F., \& Borysenko, A.V. (2000). Zabolevaniya parodonta [Periodontal disease]. Kyiv: Zdorovia [in Russian].

7. Zabolotnyi, T.D., Borysenko, A.V., Markov, A.V., \& Shylivskyi, I.V. (2011). Heneralizovanyi parodontyt [Generalized periodontitis]. Lviv: HalDent [in Ukrainian]. 8. Zabolotnyi, T.D., Borysenko, A.V. \&
Pupin, T.I. (2013). Zapalni zakhvoriuvannia parodonta [Inflammatory periodontal disease]. Lviv: HalDent [in Ukrainian].

9. Bandrivskyi, Yu.L., \& Shvets, I.Ye. (2014). Vydovyi sklad anaerobnoi mikroflory yasennykh borozen ta parodontalnykh kyshen $\mathrm{u}$ khvorykh $\mathrm{z}$ zapalnodestruktyvnymy zakhvoriuvanniamy tkanyn parodonta na foni patolohii orhaniv shlunkovo-kyshkovoho traktu [Species composition of the anaerobic microflora of gingival sulcus and periodontal pockets in patients with inflammatory and destructive diseases of periodontal tissues on the background of pathology of the gastrointestinal tract]. Visnyk problem biolohii $i$ medytsyny - Bulletin of Problems of Biology and Medicine, 4, 309-312 [in Ukrainian].

10. Petersen, P.E. (2015). The global burden of oral diseases and risk to oral health. Bull. World Health Organ., 83, 9, 661-669. 